DOI 10.31558/2519-2949.2018.4.4

УДК 342.8

Михайлова Д. С., Національний педагогічний університет ім. М. П. Драгоманова

\title{
ДОСВІД ВИБОРЧИХ СИСТЕМ УКРАЇНИ В ПОЛІТИКО-ПРАВОВОМУ АСПЕКТІ
}

У статті надається політико-правова характеристика виборчих систем Украӥни в контексті парламентських виборів. Розглядається проблема пошуку оптимальної для Украйни виборчої системи. Аналізується досвід застосування в Украӥні мажсоритарної, пропориійної та зміманої виборчих систем на виборах народних депутатів у період із 1988 по 2018 роки.

Зміна виборчого закону перед кожними парламентськими виборами свідчить про нестабільність украйнського законодавства з иьього питання. Лише із запровадженням зміманої виборчої системи у 1997 рочі політичні партї̈ стали повноцінними учасниками політичного життя. До иього народні депутати обиралися за мажоритарною системою в одномандатних округах, що призвело до нерезультативності таких виборів. Виключно пропориійна система, яка існувала з 2004 по 2011 роки, вирішила июю проблему. Проте, через застосування «закритих» списків громадяни не мали можливості впливати на персональний склад парламенту. Це перешкоджало вираженню дійсного волевиявлення електорату. Змішана система, яка застосовується сьогодні, є компромісним рішенням для прихильників мажоритарної та пропориійної систем. Проблеми, які супроводжували украӥнські вибори ще до здобуття незалежності, залишаються невирішеними.

Прийняття 7 листопада 2017 року проекту Виборчого кодексу України передбачає запровадження на виборах народних депутатів пропориійної виборчої системи з «відкритими» списками або преференційним голосуванням. Виникає необхідність обтрунтувати доцільність нової для України виборчої системи, яка пропонується для застосування на парламентських виборах. У зв'язку з цим, розглядаються позитивні та негативні характеристики мажсоритарної та пропориійної виборчих систем. Встановлено, що виборча система має сприяти вираженню реального волевиявлення вибориів, а також відповідати загальноприйнятим стандартам демократичних виборів. У статті пропонуються альтернативи по відношенню до пропориійної виборчої системи з «відкритими» списками, які зберігають переваги мажоритарної та пропориійної систем, і найбільш точно виражають реальне волевиявлення громадян.

Ключові слова: Україна; вибори; парламентські вибори; виборча система

Постановка проблеми та ї̈ зв'язок із важливими науково-практичними завданнями. Зі здобуттям незалежності в Україні існує проблема обрання доцільної виборчої системи, яка виражатиме реальне волевиявлення виборців та відповідатиме загальноприйнятим демократичним стандартам виборчого права. Важливість цього питання у тому, що саме виборча система визначає механізми обрання народних депутатів та роль виборців у виборчому процесі. М. Рибачук справедливо наголошує, що залежно від застосованої на виборах системи, перемогу можуть отримати різні політичні сили [16, с. 94].

В Україні існує проблема пошуку оптимальної виборчої системи та постійної зміни виборчого законодавства. У листопаді 2017 прийнято проект Виборчого кодексу України, який проголошує проведення виборів народних депутатів за пропорційною виборчою системою 3 «відкритими» списками. Це законодавче рішення покликано вирішити проблеми, які супроводжували виборчий процес в Україні за минулих виборчих систем. У цьому контексті особливого значення набуває аналіз переваг і недоліків пропорційної виборчої системи з «відкритими» списками. Вирішенню цього питання сприятиме порівняльний аналіз виборчих систем України.

Аналіз останніх досліджень і публікаџій. Еволюція, проблеми та перспективи виборчих систем в Україні стали предметом наукових досліджень Ю.Б. Ключковського, Н. Богашевої, О.В. Марцеляка, М. Рибачука, М. Михальченка та інших.

Виділення невирішених раніше частин загальної проблеми. У дослідженнях виборчих систем пропорційна виборча система 3 «відкритими» списками аналізується переважно як альтернатива чинній змішаній виборчій системі. Не повною мірою досліджено переваги та недоліки пропорційної виборчої системи 3 «відкритими» списками. 
Mema cmammi. Дати порівняльну характеристику виборчих систем України в політикоправовому аспекті. На основі проведеного аналізу розглянути переваги та недоліки пропорційної виборчої системи «відкритих» списків за прийнятим проектом Виборчого кодексу України.

Виклад основного матеріалу. За роки незалежності виборчі системи в Україні постійно змінювалися. Україна застосовувала мажоритарну, змішану та пропорційну виборчі системи на виборах народних депутатів. Проте, законодавство, яке регламентувало застосування виборчої системи, змінювалося кожні 5 років перед новими виборами народних депутатів України. Звідси випливає проблема нестабільності виборчого законодавства.

У чинному Законі України «Про вибори народних депутатів України» визначається, що вибори проводяться за змішаною мажоритарно-пропорційною системою [14]. Ця система поєднує характеристики мажоритарної та пропорційної систем, з усіма їх перевагами та недоліками. Проте, у листопаді 2017 року було прийнято проект Виборчого кодексу України, який передбачає перехід до пропорційної виборчої системи з відкритими списками на виборах народних депутатів. Повністю скасовується мажоритарна складова на виборах народних депутатів. Виникає питання доцільності такого рішення законодавця. Щоб з'ясувати, чи дійсно ця система вирішує проблеми, які існували за минулих виборчих систем, слід проаналізувати наявний досвід України із застосування виборчих систем.

Для визначення доцільності виборчої системи слід взяти за основу загальноприйняті критерії демократичних виборів. Так, Декларація Міжпарламентського Союзу наголошує на необхідності проведення вільних і справедливих виборів. У ст. 71 Конституції України встановлено, що вибори «є вільними і відбуваються на основі загального, рівного і прямого виборчого права шляхом таємного голосування» [5]. М. Михальченко наводить такі критерії демократичних виборів, як загальні критерії демократичних виборів, серед яких вільний та загальний характер виборів, періодичність їх проведення, гласність, альтернативність і справедливість [7, с. 269]. 3 огляду на вищенаведене, необхідно провести порівняльний аналіз виборчих систем, які застосовувалися на виборах народних депутатів України.

\section{Досвід виборчих систем України}

Ю.Б. Ключковський пов'язує наближення українських виборів народних депутатів до демократичних критеріїв із Законом СРСР від 1988 року [4]. Із тексту Закону випливає, що тоді застосовувалася мажоритарна система абсолютної більшості у першому турі парламентських виборів, та відносної - у другому [8].

Водночас, ряд положень Закону ставить під сумнів відповідність Закону 1988 року, та проведених за ним виборів 1989 року. Ю.Б. Ключковський пояснює, що призначення депутатів керівними органами організацій, а також більша кількість голосів у посадових осіб організацій порівняно з іншими виборцями, суперечили засадам рівності та загальності [4].

За Законом Української РСР від 1989 року про вибори народних депутатів, скасовувалося проведення окружних передвиборчих зборів та призначення депутатів від громадських організацій. Виборча система, порівняно із 1988 роком, не змінилася [9]. Поступову лібералізацію виборчого законодавства Ю.Б. Ключковський пов'язує з Законом 1989 року. Проте, Закон не передбачав представлення у парламенті інших партій, окрім КПРС [4]. Цей суттєвий недолік все ще віддаляв вибори від відповідності демократичним.

За Законом 1993 року, вибори проводилися у 450 округах, за мажоритарною системою абсолютної більшості. В одному окрузі міг перемогти один кандидат [10]. М. Рибачук та I. Шкурат у цілому визначали цей закон відповідним міжнародним демократичним стандартам виборів $[17$, c.90]. Проте, незважаючи на визнання ролі партій у політичному житті, процедура їх висування на вибори була обтяжливою. Для реєстрації партії як кандидата на виборах, необхідно було зареєструватися і у ЦВК, і в міністерстві юстиції. Вимагався детальний список мінімум 100 членів партії та проведення конференції обласної організації партії. 3 огляду на це, слід заперечувати відповідність Закону 1993 року міжнародним демократичним стандартам. Крім того, значним недоліком виборів за Законом 1993 року була їх нерезультативність [17, с.90]. Також через вимоги щодо явки необраними залишилися приблизно 1/3 складу Верховної Ради [4]. Ці наслідки означали необхідність перегляду існуючого виборчого законодавства у частині виборчої системи.

М. Рибачук стверджує, що основним досягненням виборів 90-х років стало створення та оформлення у правовому полі політичних партій [17, с.89]. 3 огляду на зміст закону 1993 року, із цим важко погодитися. Лише у 1997 році вдалося досягти компромісу між прихильниками 
мажоритарної та пропорційної виборчих систем, шляхом запровадження на виборах народних депутатів України змішаної системи. Ця виборча система передбачає, що частина мандатів розподіляється між депутатами відповідно до засад мажоритарної системи: кандидат, який отримав абсолютну чи відносну більшість голосів, визначається переможцем виборів. Інша частина мандатів розподіляється пропорційно, відповідно до числа поданих за партію голосів [11].

Незважаючи на усунення складної процедури, яку по праву слід вважати дискримінацією політичних партій, через рік після прийняття Закону 1997 року, жодна 330 партій, які висувалися на виборах, не отримала більшості в парламенті. Кандидати, які представляли «прохідні» партії, отримали низькі результати в одномандатних виборчих округах [17, с.91-92]. Таким чином, знову виникла потреба у зміні виборчого законодавства через виявлені недоліки.

Напередодні 2002 року виник конфлікт між парламентом і Президентом щодо нового Закону «Про вибори народних депутатів». У результаті численних ветувань із боку Президента, виборча система була залишена без змін. Спроба повністю відійти від мажоритарної системи виявилася невдалою [17, с.93].

Остаточний перехід до пропорційної системи вдалося закріпити лише у Законі від 2004 року. 3 одного боку, усувалися недоліки, які обмежували роль партій у виборчому процесі. 3 іншого, вибори проводилися за закритими списками виборців [13].

Законом від 2011 року було повернено мажоритарний елемент у вигляді змішаної пропорційномажоритарної виборчої системи [14]. За такою системою проводяться вибори і станом на січень 2018 року.

Із вищенаведеного випливає проблема нестабільності виборчого законодавства та виборчих систем, оскільки закон змінювався кожні 5 років, із проведенням наступних виборів. Цю тенденцію неможна оцінювати однозначно. 3 одного боку, це ілюструє нестабільність українського виборчого законодавства, з іншого - здатність молодої держави швидко реагувати на зміни та усувати виявлені недоліки. Тому виникає потреба у прийнятті закону, який матиме довготривалу дію та не змінюватиметься під кожні вибори.

Прийняття у першому читанні Виборчого кодексу також слід розглядати як реакцію на недоліки змішаної виборчої системи. Відповідно до положень Кодексу, на виборах народних депутатів застосовується пропорційна система відкритих списків. Повністю скасовується мажоритарна складова.

В українській політичній думці немає єдиної точки зору доцільності та перспектив цієї системи. Тому необхідно порівняти типи виборчих систем, які вже застосовувалися в Україні, разом із їх перевагами та недоліками.

\section{Переваги та недоліки виборчих систем України}

Мажоритарна система передбачає перемогу кандидата, який набрав більшість голосів. М. Рибачук визначає переваги мажоритарної виборчої системи у можливостях:

- формування ефективно працюючого, однопартійного уряду;

- легка перемога добре організованих партій [16, с.95].

М. Скубішевський наводить таку перевагу, як можливість переможців реалізовувати передвиборні програми та формувати більшість у парламенті. Зменшується вірогідність відсутності уряду [18]. Тому слід стверджувати про більш стабільні уряд і коаліцію за умови застосування мажоритарної системи.

Серед недоліків мажоритарної системи - «втрачені» голоси за кандидата, який не виграв вибори. Як наслідок, значна частина виборців залишається непредставленою в органах державної влади. Партія може одержати менше голосів виборців, але отримати більше місць у представицькому органі $[17$, с.95]. У такому випадку не відображається дійсне волевиявлення виборців.

М. Скубішевський стверджує про негативне ставлення в Україні до мажоритарної системи через отримання більшості в парламенті представниками Партії Регіонів у 2012 році, не без застосування маніпуляцій. Тоді результати виборів у п'яти округах не вдалося встановити через численну кількість порушень [18]. Втім, слід погодитися із М. Скубішевським у тому, що мажоритарну систему не слід ототожнювати з перемогою Партії Регіонів, оскільки ця система застосовувалася на виборах народних депутатів України до ії остаточної заміни пропорційною у 2004 році та повернення у 2012 році [18].

М. Скубішевський також наводить приклад Великобританії, де понад 50 років застосовується система відносної більшості, а також Франції з мажоритарної системи абсолютної більшості. 
У Великобританії взагалі не було випадків відсутності уряду, у Франції - із 1958 року [19]. Втім, слід погодитися із М. Михальченком у тому, що застосування мажоритарної виборчої системи відносної більшості можливе лише у державах зі сталими традиціями, де між собою змагаються дві

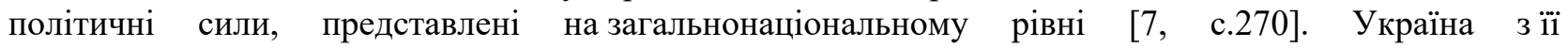
багатопартійністю не підпадає під ці характеристики.

Запровадження суто пропорційної системи на виборах народних депутатів України мало місце у 2004 та 2006 роках. До цього пропорційна система діяла лише як складова змішаної системи у 1998 та 2002 роках. Пропорційна виборча система означає, що вибори проводяться за списками політичних партій, а мандати розподіляються між переможцями відповідно до числа поданих голосів, встановлюється прохідний бар'єр для можливості партії бути представленою в парламенті.

На думку М. Рибачука, саме за пропорційної виборчої системи представницький орган відображає реальну картину політичного життя суспільства, зростає політичний плюралізм, закріплюється багатопартійність та розвивається громадянське суспільство [17, с.96]. О. Марцеляк наводить такі переваги пропорційної системи виборів:

- зменшується кількість невикористаних голосів виборців у порівнянні з мажоритарною, більший вплив виборців на формування представницького органу.

- зростає роль партій у політичному житті суспільства [6, с.11].

Водночас, при застосуванні виборчої системи із закритими списками відбувається усунення виборців від впливу на формування представницького органу. М. Михальченко характеризує ії як систему партійного списку, де контроль за розташуванням кандидатів у виборчому списку здійснюється політичними партіями, а не виборцями [7, с.271]. На думку О. Марцеляка, така тенденція веде до узурпації влади верхівкою партії [6, с.12]. Ці характеристики є особливо доречними стосовно пропорційної системи з закритими списками, де виборець втрачає свій вплив на кандидатів.

Крім того, перевага мажоритарної системи є недоліком для пропорційної. Як стверджує М. Скубішевський, внаслідок проведення виборів за пропорційною системою у 2006 році були проведені переговори щодо формування уряду. Це, у свою чергу, призвело до становлення уряду В. Януковича, що не відповідало волі більшості виборців [19].

Це ставить під сумнів можливість пропорційної системи виражати дійсну волю виборців. О.В Марцеляк із цього приводу стверджує, що вадою пропорційної системи є створення коаліції, де відсутнє порозуміння між учасниками. Також ігноруються особисті якості кандидатів [6, с.11-12]. При такому непорозумінні політичний курс залишається невизначеним.

Як показує розглянутий вище досвід України у застосуванні виборчих систем, запровадження компромісного рішення у вигляді змішаної виборчої системи не вирішує нагальних проблем мажоритарної та пропорційної складових. Альтернативою у такому випадку може слугувати пропорційна система з відкритими списками. Вона поєднує позитивні риси як мажоритарної, так i пропорційної систем виборів. Зокрема, виборець отримує змогу чинити вплив на політичні партії [2, с.4-5]. Необхідність відійти від пропорційної складової змішаної системи із закритими списками та заміна їі відкритими списками проголошувалася ще у Резолюції ПАРЄ 1755 (2010) «Функціонування демократичних інституцій в Україні». Відповідно до підпункту Резолюції 7.1.2, наголошувалося на необхідності запровадження відкритих списків, що повністю відповідає європейським стандартам [16]. Дійсно, майже у межах усього Європейського Союзу застосовуються виборчі системи із преференційним голосуванням, яке передбачає відкриті списки. Винятком є лише Угорщина, де, як i в Україні, на парламентських виборах все ще застосовуються закриті списки [2, с.3-4].

В аналітичній доповіді про виборчі системи Національного Інституту Стратегічних Досліджень наводяться такі переваги пропорційної виборчої системи з відкритими списками:

- суспільна легітимація - збільшення довіри до виборів із боку населення;

- преференційне голосування - можливість виборців голосувати за окремих кандидатів зі списків партій та впливати на порядок розташування кандидатів у списках [2, с.4-6].

Проте, навіть ця система не позбавлена недоліків. На думку М. Скубішевського, навіть пропорційна виборча система з відкритими списками не завжди відображає реальне волевиявлення виборців. Наприклад, у 2005 році у Польщі застосовувалася подібна виборча система. Виборці сподівалися на формування антикомуністичної коаліції внаслідок проведення виборів. Проте, партія «Право та справедливість» братів Качинських об’єдналася із радикалами ЛПР («Ліга Польських Родин» та «Самообороною»), чим не виправдала очікувань електорату [19]. 
Серед інших недоліків пропорційної системи є:

- звернення уваги виборців лише на «відомих» кандидатів;

- обрання кандидата, непопулярного або невідомого в межах округу;

- Дві вищевказані характеристики ставлять під сумнів дійсне волевиявлення виборців;

- залишається залежність від керівництва партії, оскільки саме від його рішень залежить перспектива висування кандидата [19].

Аналітична доповідь про виборчі системи Національного Інституту Стратегічних Досліджень розкриває такі перспективи відкритих списків в Україні:

1. Запровадження на виборах народних депутатів України пропорційної виборчої системи з відкритими списками не впливатиме на стабільність правлячих коаліцій.

2. «Відкриті списки» сприятимуть конкуренції та чіткому розмежуванню політичних сил;

3. Підвищення «ваги» популярних партій означає, що за нової виборчої системи парламент нового скликання мало відрізнятиметься від нинішнього, оскільки найпопулярніші $\epsilon$ найвпливовішими.

4. «Відкриті списки» не впливатимуть на зміцнення місцевих бізнес-угруповань та їх вплив на загальнонаціональному рівні, оскільки корупційні змови стосуватимуться не місць у «першій п’ятірці», а місць у регіональному списку

5. Поява нових політичних сил сприятиме вирішенню питань локального значення [2, с.8-11].

3 огляду на «більшість популярних», слід замість загальнонаціонального застосувати регіональний округ при відкритих списках. [2, с.8].

У Пояснювальній записці до Проекту Виборчого кодексу України вказуються такі перспективи прийняття цього законопроекту:

1. Персоніфікація голосування;

2. Підтримка загальноукраїнського характеру політичних партій та недопущення їх регіоналізації та міжрегіональних конфліктів;

3. Стабілізація законодавства про вибори [15].

Перспективи пропорційної виборчої системи з «відкритими» списками

Слід окремо відмітити, що запровадження пропорційної виборчої системи 3 «відкритими» списками дійсно вирішить проблему, яка існувала на виборах 2014 року - «прикриття відомими особами». Тоді для забезпечення перемоги партії на виборах до іiі списків включалися відомі журналісти, активісти та інші відомі державні та культурні діячі [1].За неможливістю обирати серед кандидатів усписку партії голосування здійснювалося на основі особистих уподобань щодо конкретної особи. Таким чином, не виражалося дійсне волевиявлення виборців. Це ще раз підтверджує тезу про персоніфікацію голосування.

Дискусію навколо доцільності цього типу виборчої системи слід завершити висновком Венеціансьої комісії: «немає жодних підстав, щоб зробити абсолютний вибір на користь будьякої конкретної виборчої системи. Кожна має свої переваги і свої недоліки, які варіюються залежно від того, які функції, що їх виконує виборча система, є предметом розгляду. Жодна виборча система не може бути найкращою або найгіршою чи хоча б хорошою або поганою. Для того щоб оцінити їі якість, необхідно точно знати, що від неї очікується - що в першу чергу очікується, - оцінюючи те, яким чином вона виконує свої різні, часом суперечливі функції, а саме функції виборчої системи в контексті демократичної політичної системи» [Цит.3: 3, с. 116; 129]. Слід погодитися з тим, що кожній виборчій системі притаманні недоліки, розглянуті вище. Втім, постійні «пошуки» найбільш прийнятної системи призводять до нестабільності законодавства про вибори.

Позитивною рисою пропорційної системи з відкритими списками є персоніфікація голосування. М. Скубішевський при порівнянні пропорційної та мажоритарної систем наголошував, що голосування повинно бути персоніфікованим [19]. На мою думку, можливість обрання конкретних осіб $є$ компромісом між прихильниками мажоритарної та пропорційної систем. Проте, іiї не слід сприймати як вирішення всіх проблем українських виборів, у тому числі їх корупційної складової. М. Михальченко також не рекомендує розглядати виборчу систему як вирішення усіх нагальних проблем, оскільки замість таких сподівань слід зосередитись на виборі системи, найбільш оптимальної для конкретних часів та умов [283-284]. Беззаперечно, виборча система напряму залежить від соціально-політичних умов, а не прийнятих у певній країні правових норм. Водночас, не слід нехтувати зарубіжним досвідом. М. Михальченко рекомендує адаптувати вже наявний досвід зарубіжних країн до політичних реалій України [7, с.285]. 
На мою думку, така адаптація має здійснюватися шляхом застосування такої складової пропорційної системи, як система єдиного голосу, що передається. Приклад застосування можна спостерігати в Австралії, Ірландії, певних адміністративно-територіальних одиницях Індії (штатах) [7, с.271]. За такої системи виборці мають більшу свободу вибору. При обранні кандидатів не береться до уваги їх партійна належність, оскільки виборець може вказати кілька преференцій до більше, ніж одного кандидата, не обмежуючись переліком кандидатів від певної партії [17, с.54]. При цьому зберігається позитивна риса, властива мажоритарній системі - голосування стосується особи, а не партії. Таким чином, збільшується вплив виборців на виборчий процес, представлення їх інтересів на загальнонаціональному рівні. Із збереженням позитивних характеристик мажоритарної системи, голоси не пропадають, якщо кандидат не отримав прохідного місця, або отримав надлишок за встановленою квотою [7, с.272]. Як і змішана система, вона поєднує характеристики обох систем. Проте, на відміну від змішаної, система переданого голосу виключає недоліки, які перешкоджали представленню інтересів значної частини виборців.

\section{Висновки}

Вибір оптимальної виборчої системи для України був і залишається дискусійним питанням. Від цього залежить можливість певної політичної сили отримати перемогу на виборах.

Україна має широкий досвід у застосуванні мажоритарної, пропорційної та змішаної виборчих систем на виборах народних депутатів. Проте, виборчі системи змінювалися кожні 5 років, перед черговими виборами. Це вказує на нестабільність українського законодавства про вибори. Виникає потреба у запровадженні довготривалої виборчої системи, яка не буде скасована чи змінена перед наступними парламентськими виборами.

При обгрунтуванні доцільності конкретної виборчої системи за основу береться як наявний досвід України, так і досвід зарубіжних держав. Крім того, враховується здатність виборчої системи виражати дійсне волевиявлення виборців та їі відповідність демократичним засадам.

Проте, як показує приклад Великобританії та США, успішність виборчої системи в одній країні не означає таку саму їі успішність в іншій. Виборча система, яка функціонує в Великобританії понад 50 років, в Україні стала об’єктом маніпуляцій та зловживань із боку кандидатів. 3 огляду на це, необхідно враховувати політичні умови конкретної держави.

Подібні зловживання спостерігалися і з пропорційною системою, коли до закритих списків партій включалися державні та культурні діячі, з метою отримання найбільшої кількості голосів електорату.

Прийнята у листопаді 2017 року пропорційна система з відкритими списками дійсно персоніфікує голосування, збільшує можливості виборців впливати на склад парламенту. Проте, зберігається вирішальний вплив партій при висуванні кандидатів.

Враховуючи переваги та недоліки кожної з застосованих в Україні виборчих систем, неможна категорично рекомендувати впровадження мажоритарної та пропорційної системи. Не вирішує питання і залишення змішаної системи.

Тому компромісним рішенням є пропорційна система передаваного голосу. Вона включає позитивні риси як мажоритарної, так і пропорційної виборчих систем. Крім того, посилюється персоніфікація голосування, оскільки виборці не обмежені конкретною партією. 3 огляду на це, саме цю систему слід запровадити на виборах народних депутатів, оскільки саме вона найточніше виражає дійсне волевиявлення виборців та відповідає загальноприйнятим демократичним стандартам виборів.

\section{Бібліографічний список:}

1. Выборы в Раду: в тренде - комбаты, журналисты, активисты [Електронний ресурс] - Режим доступу: https://telegraf.com.ua/ukraina/obshhestvo/1483884-vyiboryi-v-radu-v-trende-kombatyi-zhurnalistyi-aktivistyi.html

2. Доповіді про виборчі системи: огляд можливих розв'язків та критерії вибору, ухваленої на 57 пленарній сесії 12-13 грудня 2003 року

Запровадження виборчої системи з відкритими списками: можливий вплив на політичну систему України [Електронний ресурс] // Офіційний веб-сайт Національного Інституту Стратегічних досліджень - Режим доступу. - http://www.niss.gov.ua/content/articles/files/Yanishevskyi_vidkr_sp-60a2d.pdf

3. Європейський демократичний доробок у галузі виборчого права: матеріали Венеціанської Комісії, Парламентської Асамблеї, Комітету Міністрів, Конгресу Місцевих і Регіональних влад Ради Свропи: пер. 3 англ. / За ред. Ю.Б. Ключковського. - вид.2-е, випр. і доповн. - К.:2009. - 500 с.

4. Ключковський Ю. Еволюція виборчої системи України [Електронний ресурс] / Ю. Ключковський, Н. Богашева // Офіційний веб-сайт Центральної виборчої комісії України. - Режим доступу. http://www.cvk.gov.ua/visnyk/index.php?mID=12 
5. Конституція України від 28 червня 1996 року [Електронний ресурс] // Офіційний веб-сайт Верховної Ради України. - Режим доступу: http://zakon1.rada.gov.ua/laws/show/254k/96-вp

6. Марцеляк О.В. Конституційна реформа і модернізація виборчої системи України в контексті світового досвіду / Олег Марцеляк // Наукова бібліотека. - 2015. - с. 8-12.

7. Михальченко М., Самчук 3. Виборчі системи: зарубіжний досвід / Микола Михальченко, Зореслав Самчук // Наукові записки. - №50. - с. 267-286.

8. Про вибори народних депутатів Союзу Радянських Соціалістичних Республік: Закон СРСР №9855-XI від 01 грудня 1988 року [Електронний ресурс] // Офіційний веб-сайт Верховної Ради України. - Режим доступу: http://zakon2.rada.gov.ua/laws/show/v9855400-88

9. Про вибори народних депутатів Української РСР: Закон Української РСР№8304-ХІ від 27 жовтня 1989 року [Електронний ресурс] // Офіційний веб-сайт Верховної Ради України. - Режим доступу: http://zakon5.rada.gov.ua/laws/card/8304-11/ed19891027

10. Про вибори народних депутатів України: Закон України №3623-ХІІ від 18 листопада 1993 року [Електронний ресурс] // Офіційний веб-сайт Верховної Ради України. - Режим доступу: http://zakon5.rada.gov.ua/laws/show/3623-12

11. Про вибори народних депутатів України: Закон України №541/97-ВР від 24 вересня 1997 року [Електронний ресурс] // Офіційний веб-сайт Верховної Ради України. - Режим доступу: http://zakon5.rada.gov.ua/laws/card/541/97-\%D0\%B2\%D1\%80

12. Про вибори народних депутатів України: Закон України № 2766-III від 18 жовтня 2001 року [Електронний ресурс] // Офіційний веб-сайт Верховної Ради України. - Режим доступу: http://zakon2.rada.gov.ua/laws/show/2766-14

13. Про вибори народних депутатів України: Закон України № 1665-IV від 25 березня 2004 року [Електронний ресурс] // Офіційний веб-сайт Верховної Ради України. - Режим доступу: http://zakon3.rada.gov.ua/laws/show/1665-15

14. Про вибори народних депутатів України: Закон України №4061-17від 17 листопада 2011 року [Електронний ресурс] // Офіційний веб-сайт Верховної Ради України. Режим доступу: http://zakon4.rada.gov.ua/laws/show/4061-17.

15. Проект Виборчого Кодексу України 3112-1 від 02 жовтня 2015 року [Електронний ресурс] // Офіційний веб-сайт Верховної Ради України. - Режим доступу: http://w1.c1.rada.gov.ua/pls/zweb2/webproc4_1?pf3511=56671

16. Резолюція ПАРС 1755 (2010) «Функціонування демократичних інституцій в Україні» від 04 жовтня 2010 року [Електронний ресурс] // Офіційний веб-сайт Верховної Ради України. - Режим доступу: http://zakon3.rada.gov.ua/laws/show/994_a19

17. Рибачук М., Райковський Б. Аналіз концепцій сучасних моделей виборчих систем // Політичний менеджмент. - 2009. - № 3. - С. 45-54.

18. Рибачук М. Історичні аспекти становлення виборчої системи України / Микола Рибачук, Іван Шкурат // Політичний менеджмент. - 2004. - №1. - с.83-98.

19. Скубішевський М. Чому Україні потрібна мажоритарна виборча система [Електронний ресурс] / М. Скубішевський // Українська Правда. - 2014. - Режим доступу: http://www.pravda.com.ua/columns/2014/08/21/7035437/

20. Declaration on criteria for free and fair elections [Електронний ресурс] Режим доступу: http://www.ipu.org/cnl-e/154-free.htm.

\section{Mykhailova D. Practice of election systems of Ukraine in political and legal aspects}

The article provides political and legal characteristic of electoral systems of Ukraine. The considered problem lies in finding an optimal electoral system for Ukraine. Also, the article analyzes the experience of applying the majoritarian, proportional and mixed electoral systems in the parliamentary elections in the period of 1988 to 2018 years.

Amendments, which have been made to the electoral law prior to each parliamentary elections, have shown instability of the law regulating such issue. Only after introducing the mixed electoral system in 1997 political parties have become full-fledged participants of the political life. Earlier members of parliament were elected according to the majoritarian system in single-member constituencies. This procedure led to ineffectiveness of such elections. Exclusive proportional system, which has been existed from 2004 till 2011, resolved this problem. However, citizens did not have a right to influence on personal parliament composition. These circumstances impeded expression of actual will of electorate. Mixed system applicable at the present time, is a compromise decision for admirers of both majoritarian and proportional systems. Problems, which followed Ukrainian elections even prior to getting an independence, remain unresolved.

Adoption of the bill of Electoral Code of Ukraine on November 07, 2017 prescribes implementation of the proportional system with "open" lists or preferential vote for the elections of members of parliament 
of Ukraine. There is a necessity to justify the relevance of new electoral system proposed for use in parliamentary elections. In this regard, the article considers positive and negative characteristics of the majority and proportional electoral systems. It has been clarified that the electoral system should promote the real will of the electorate, as well as comply with generally established standards of democratic elections. The article proposes alternatives to the proportional electoral system with "open" lists that preserves the merits of majoritarian and proportional systems, and most accurately expresses the real will of the citizens.

Keywords: Ukraine; elections; parliamentary elections; electoral system 